\title{
Hubungan Antar Manusia
}

\author{
Azizah \\ Universitas Negeri Padang \\ E-mail
}

Azizahjeara16@gmail.com

\begin{abstract}
Abstrak
Tujuan penuliasan artikel ini adalah untuk menjelaskan mengenai konsep hubungan antar manusia. Artikel ini akan menguraikan pegenrtian hubungan antar manusia, factor- factor yang mempenagruhi hubungan antar manusia, teknik- teknik hubungan antar manusia dan hambatan dalam hubungan antar manusia. Artikel ini merujuk kepada jurnal- jurnal yang ditulis oleh orang- orang yang ahli. Diharapkan artikel ini dapat menjadi rujukan dalam mendapatkan informasi mengenai hubungan anatar manusia Kata Kunci : Hubungan antar manusi, komunikasi
\end{abstract}

\section{PENDAHULUAN}

Manusia adalah makluk sosial. Kelebihan manusia sebagai makluk social adalah kesediaannya memberikan pertolongan kepada orang lain. Tingkah laku menolong ialah yang memberikan faedah dan keuntungan bagi orang lain. Untuk bertahan hidup, harus ada sosialisme atau berhubungan dengan manusia lain dan hal ini tidak dapat dihindari, mutlak di butuhkan manusia. Hubungan antar manusia dengan hubungan kemanusiaan sesungguhnya memiliki pengertian yang berbeda. Dalam setiap bentuk hubungan antar manusia lebih mendominasi daripada hubungan kemanusiaan. Dalam pengertian hubungan antar manusia bukan hanya dalam wujudnya saja tetapi juga dalam sifat-sifatnya, waktunya, cara bicaranya, sikapnya, tingkah lakunya, pribadinya, dan berbagai macam aspek kejiwaan yang apa pada diri manusia. Dalam pergaulan hidup manusia memiliki fungsi yang bermacam-macam seperti disuatu organisasi di satu sisi ia sebagai pemimpin atau kepala dalam suatu bidang, dan di sisi lain dia juga sebagai bawahan atau karywan dalam organisasi tersebut.

\section{KAJIAN TEORI}

\section{A. Pengertian Hubungan Antar Manusia}

(Ermita, 2012) Hubungan antar manusia (HAM) merupakan salah satu faktor yang mempengaruhi semangat kerja pegawai. Adapun yang dimaksud dengan HAM menurut Sarwoto (Ermita, 2012) adalah keseluruhan hubungan baik yang formal maupun informal yang perlu diciptakan dan dibina dalam suatu organisasi sedemikian rupa sehingga tercipta 
iklim kerja yang intim dan harmonis dalam rangka pencapaian tujuan yang telah ditentukan Selanjutnya, Effendy menyatakan bahwa: Hubungan antar manusia pada dasarya disebut juga dengan istilah Human Relations, pemberian makna terhadap proses rohaniah yang tertuju kepada kebahagian dan kepuasan yang berdasarkan watak, sifat, perangai, kepribadian, tingkah laku dan lain-lain aspek kejiwaan yang terdapat pada diri manusia.

Hubungan antar manusia adalah "hubungan kemanusiaan yang harmonis, tercipta atas kesadaran dan kesediaan melebur keinginan individu demi kepentingan bersama. Kemudian Siagian (1999:7) dalam (Ermita, 2012) menjelaskan bahwa hubungan antar manusia adalah keseluruhan rangkaian hubungan yang bersifat formal antara atasan dengan bawahan, atasan dengan atasan, serta antara bawahan dengan bawahan lain yang harus dibina dan dipelihara sedemikian rupa, sehingga tercipta suatu team work dan suasana kerja yang intim dan harmonis dalam rangka pencapaian tujuan.

Effendy (Ermita, 2012) mengemukakan ada dua pengertian hubungan antar manusia, yakni hubungan dalam arti luas dan arti sempit. Dalam arti luas hubungan antar manusia adalah :komunikasi persuasif yang dilakukan seseorang kepada orang lain secara tatap muka dalam segala situasi kehidupan, sehingga menimbulkan kebahagiaan pada kedua belah pihak. Sedangkan hubungan antar manusia dalam arti yang sempit yaitu : komunikasi persuasif yang dilakukan seseorang kepada orang lain secara tatap muka dalam situasi kerja (work situation) dan dalam organisasi kekaryaan (woerk organization untuk menggugah kegairahan dan kegiatan untukbekerja dengan semangat kerjasama yang produktifdengan perasaan bahagia dan puas hati.

Berdasarkan pendapat di atas dapat disimpulkan bahwa hubungan antar manusia adalah kegiatan komunikasi persuasif yang bukan hanya sekedar relasi atau hubungan saja melainkan suatu aktivitas dan suatu kegiatan untuk mengembangkan hasil yang rasa bahagia dan rasa puas, serta kegiatan untuk meningkatkan dan mengembangka lebih produktif dan memuaskan. Komunikasi persuasif yang dimaksud di sini adalah komunikasi yang bersifat membujuk agar tercipta hubungan yang baik.

(Widodo \& Susanti, 2010) Hubungan manusiawi adalah terjemahan dari human relation. Orang-orang juga ada yang menterjemahkan menjadi "hubungan manusia" atau juga diterjemahkan "hubungan antar manusia", yang sebenarnya tidak terlalu salah karena yang berhubungan satu sama lain adalah manusia. Hanya saja, disini sifat hubungan sesama manusianya tidak seperti orang berkomunikasi biasa, bukan hanya merupakan 
penyampaian suatu pesan oleh seseorang kepada orang lain, tetapi hubungan antara orang-orang yang berkomunikasi dimana mengandung unsur-unsur kejiwaan yang amat mendalam.

Hamalik ( 1993), dalam penetapan kebijaksanaan tentang hubungan antara manusia, seperti karyawan dalam organisasi dapt dilakukan melalui tiga alternative pandangan, yakni:

a. Kepentingan organisasi sebagai factor yang menentukan untuk mencapai maksud-maksud ekonomi sedangkan kariawan harus menyesuaikan diri terhadap permintaan dan tuntutan organisasi dan karenanya merekan harus bekerjasama

b. Membentuk kondisi, fungsi dan tujuan organisasi dengan cara memenuhi kebutuhan dan minat para karyawan sehingga terjadi ketergantungan kariawan kepada organisasi.

c. Tanggungjawab manajemen mengacu pada minat karyawan dan organisasi dibangun sehingga membangun karyawan sendiri yang memenuhi kebutuhan dan ambisinya.

B. Faktor- Faktor yang mempengaruhi Hubungan antar Manusia

Hubungan antar manusia pada dasarnya adalah aktivitas komunikasi (interpersonal). Jadi antara HAM dengan komunikasi atau komunikasi dengan HAM saling berkaitan, untuk itu ada beberapa indikator yang dapat mempengaruhi HAM dalam komunikasi Interpesonal

Menurut Rahmat dalam (Ermita, 2012) factor faktor tersebut adalah "saling menghargai, empati, keterbukaan/sikap terbuka, kepercayaan, dan kehangatan". Untuk lebih jelasnya factor tersebut akan diuraikan secara ringkas satu persatu.

Untuk lebih jelasnya factor tersebut akan diuraikan secara ringkas satu persatu.

\section{a. Saling Menghargai}

Saling menghargai artinya saling menghormati atau mengindahkan satu sama lain dalam suatu hubungan antar manusia akan terjadi secara efektif apabila satu sama lain dapat saling menghargai, bersifat positif dan wajar tanpa menilai atau keberatan”. Menghargai berarti saling menghormati, memperhatikan dan mendengarkan satu sama lain atas kerja, karya, usulan, ide dan pengabdian dalam suatu organisasi.

\section{b. Empati}

Empati merupakan salah satu kunci dari keberhasilam terbinanya hubungan antar manusia. Empati berarti bisa merasakan apa yang dirasakan komunikan tersebut, maka mungkin sekali komunikator da menyampaikan pesan yang tepat kepadanya. Lebih sempit empati berarti seperasaan dengan orang lain, artinya ikut merasakan apa yang dirasakan 
orang lain, sehingga dalam proses komunikasi interpersonal akan lebih efefktif dan lebih bermakna sesuai dengan tujuan komunikasi interpersonal tersebut.

\section{c. Keterbukaan/Sikap Terbuka}

Sikap terbuka aau keterbukaan dalam suatu hubungan antar manusia sangat pentingartinya bagi kelangsungan hubungan antar manusia tersebut. Menurut Rahmat (Ermita, 2012) menyatakan bahwa : Bersamasama dengan sikap percaya,dan sikap suportif, sikap terbukamendorong timbulnya saling pengertian, saling menghargai, dan paling pentingsaling mengembangkan interersonal.Pendapat e. Kehangatan

\section{kualitashubungan}

tersebut menjelaskan bahwa sikap keterbukaan merupakan hal penting dalam mengembangkan hubungan interpersonal atau hubungan antar manusia. Sikap terbuka mempunyai karakter sebagai berikut : menilai pesan secara objektif, membedakan dengan mudah, melihat nuansa bukan berfikir simplistis (tanpa nuansa), beroreantasi pada isi bukan sumber pesan, informasi diperoleh dari berbagai sumber, dan lebih bersifat provisional artinya tidak secara kaku mempetahankan atau memegang teguh system kepecayaan.

\section{d. Kepercayaan}

Faktor lain yang dapat menumbuhkan HAM dalam komunikasi interpesonal adalah kepercayaan. Secara ilmiah "kepercayaan" menurut Rahmat (1998: 29) adalah "mengandalkan perilaku orang lain untuk mencapai tujuan yang dikehendaki. Unsur yang penting dalam kepercayaan adalah situasi yang penuh resiko bagi orang yang menaruh kepercayaan ( sikap orang diberikan kepercayaan pada dasarnya tidak pasti, artinya bisa dipercaya dan bisa juga berkhianat atau tidak dapat dipercaya. Namun demikian unsure kepercayaan ini yang harus dikembangkan dalam hubungan antar manusia adalah mau memberikan wewenang kepadaorang lain yang dipercaya, mau mengandalkan perilaku orang lain dalam bekerja, dan memberikan amanah tehadap orang yang dipercaya.

Kehangatan merupakan suatu keadaan gembira atau suka cita. Agar hubungan interpersonal cenderung menjadi sempurna, maka kedua belah pihak harus mengenal standar. Salah satu standarnya adalah "mengkomunikasikan suatu kehangatan pemahaman yang positif mengenai orang lain dengan gaya mendengarkan dan merespon" pada saat lawan bicara menyampaikan pesannya. Jadi indikasi yang menunjukan adanya kehangatan dalam hubungan antar manusia adalah adanya perasaan gembira dalam mendengarkan dan gembira dalam memberikan respon.

\section{Teknik-teknik dalam Hubungan Antar} Manusia 
Widodo dan Febri Susanti (2010), Hubungan manusiawi dapat dilakukan untuk menghilangkan hambatan-hambatan komunikasi, meniadakan salah pengertian dan mengembangkan segi konstruktif sifat tabiat manusia. Dalam derajat intensitas yang tinggi, hubungan manusiawi dilakukan untuk menyembuhkan orang yang menderita frustasi. Frustasi timbul pada diri seseorang akibat suatu masalah yang tidak dapat dipecahkan olehnya. Akan tetapi masalah yang bagaimanapun akan diusah akan supaya hilang. Orang tidak akan membiarkan dirinya dipusingkan oleh masalah. Dan masalah orang yang satu tidak sama dengan masalah orang lain.

\section{Hambatan dalam Hubungan Antar Manusia}

(Widodo \& Susanti, 2010) Hambatan dalam hubungan antar manusia pada umumnya mempunyai dua sifat yaitu objektif dan subjektif. Hambatan yang sifatnya objektif adalah gangguan dan halangan terhadap jalannya hubungan antar manusia yang tidak disengaja dan dibuat oleh pihak lain tapi mungkin disebabkan oleh keadaan yang tidak menguntungkan. Hambatan yang bersifat subjektif adalah yang sengaja dibuat oleh orang lain sehingga merupakan gangguan, penentangan terhadap suatu usaha komunikasi.

\section{PENUTUP}

\section{A. Kesimpulan}

Hubungan Antar Manusia menurut Sarwoto (Ermita, 2012) adalah keseluruhan hubungan baik yang formal maupun informal yang perlu diciptakan dan dibina dalam suatu organisasi sedemikian rupa sehingga tercipta iklim kerja yang intim dan harmonis dalam rangka pencapaian tujuan yang telah ditentukan. Ada beberapa faktor yang mempengaruhi hubungan antar manusia, yaitu saling menghargai, empati, terbuka, kepercayaan dan kehangatan.

Teknik dalm hubungan antar manusia dapat dengan cara mengembangkan segi- segi konstruktif, komunikasi, dll. Dan ada juga beberapa hambatan dalam hubungan anatara manusia yaitu ada hambatan objektif dan ada hambatan subjektif.

\section{B. Saran}

Kita sebgai makhluk sosisl membutuhkan ornag lain, untuk itu kita perlu memperhatikan hubungan antar manusia, dengan memperhatikan bebrap hal diatas. Dan untuk artikel ini masih belum sempurna, untuk itu saya butuh kritik dan saran dari pembaca 


\section{DAFTAR PUSTAKA}

Ermita. (2012). Hubungan Antar Manusia dan

Semangat Kerja Pegawai. Jurnal Pedagogi,

12(2), 70-81.

Widodo, B. H., \& Susanti, F. (2010). Pengaruh

Human Relation ( Hubungan Antar Manusia

), Lingkungan kerja Terhadap Etos Kerja

karyawan ( Studi Kasus Pada PT . Pelindo

Teluk Bayur Padang ). 1-14. 
